\title{
Privatization as the Source of Organizational Change in the Israeli Labor Federation (The Histadrut): An Israeli Case Study
}

Yaffa Moskovich*

Zefat Academic college, Halmish street 4/21, Haifa- Israel, Research kibbutz institute, Haifa university

\begin{abstract}
The original Histadrut was founded as a welfare agency, as a socialist entity the Histadrut was politically and economically linked to the Labor Party which helped fund it while in government. The purpose of this research is to analyze how the process of privatization affected the goals of the Histadrut, as it evolved from being a super-organization dominating most of Israeli society to a mere confederation of labor unions. This research was conducted by case study analysis: using two methods of data collection - analyzing documents and interviews. The finding show, that Histadrut was highly politicized, and this led to the organization's incurring heavy debts. In 1994, a new leader, Haim Ramon, was elected and coped with its organizational decline. He transformed the Histadrut into a confederation of autonomous labor unions, selling off Histadrut enterprises and assets to private investors, and severing all political ties. The Histadrut underwent organizational change, downsizing and focusing on trade union goals. The main conclusion from this research is: The privatization process in the Israeli labor unions created a new organization focusing on its trade union's goals, losing its uniqueness as a society-wide entity.
\end{abstract}

Keywords: Goal Transformation, Union Leaders, Privatization, Trade Unions

\section{Introduction}

The Histadrut (General Federation of Laborers in the Land of Israel) was founded in 1920. After decades of stability, it underwent organizational change when, in 1994, the Labor party relinquished its leading role, and an outsider, Haim Ramon, was elected to run the Histadrut. He initiated a process of downsizing and privatization in the organization. In 1995, as Health Minister in Shimon Peres's government, he enacted the National Health Law. Under the new law, the Histadrut was divested of Kupat Holim Clalit, its health-service provider and Israel's largest HMO (Health maintenance organization). With taxpayers' money now going to the government to provide health-care services, rather than to the HMOs, the Histadrut lost its main source of income, which magnified its financial difficulties (Ramon, 1995) and ultimately led to total privatization (Reinhart, 1999).

\subsection{Historical Background on Case Study}

The Histadrut was established in 1920 by Jewish pioneers, with the aim of organizing the economic activity in pre-state Jewish society. It founded factories, as well as organizations to help the new settlements, such as Bank Hapoalim ("Laborers' Bank"), and 
Kupat Holim Clalit health care services. In addition, it established retail stores open to the general public - not only to Histadrut members - construction companies and social-aid services (Bartal, 1989; Shapiro, 1977). The labor unions were concerned with the wellbeing of the workers. At the same time, as the owner of Koor and other manufacturing and service enterprises, the Histadrut also represented the interest of the management - that is, of itself (Greenberg, 1993).

Before the establishment of the State of Israel in 1948, the Histadrut was the administrative mechanism of the dominating party - MAPAI (Hebrew acronym for Workers' Party of the Land of Israel).The organization recruited political support using the recourses it received from the Zionistic Federation. After the state's establishment, many Histadrut leaders held high positions in government, adding another element of conflict - this time between the law makers and the financially powerful and influential Histadrut (Shapiro, 1977).

In the 1950s, Histadrut Secretary Pinchas Lavon, wanted to increase the organization's power. However, his policy contradicted Prime Minister David Ben-Gurion's national perception with the goal of controlling all national organizations and supervising their actions (Horowitz \& Lisak, 1977; Greenberg, 1993).

The Histadrut, government, and MAPAI were strongly linked. MAPAI was dependent on the Histadrut which helped it recruit new members, resources, and voters by supplying them with work and accommodation. The Histadrut needed the government's help to sanction its activities, and the government was dependent on the party regarding wages.

The Histadrut dominated the Israeli economy until the mid 1970s. In the 1960s and early 1970s it enjoyed strong government support, especially from Minister of Finance Pinchas Sapir. The status of the labor unions changed when the right-wing Likud was elected to government in 1977. The Likud aimed to weaken the Histadrut, and under the Likud govern- ment the Histadrut did not receive resources and aid in crisis. During 1980-1994 the Histadrut began selling off its factories to cover its losses and repay debts (Greenberg, 2004). There was a major change in 1994, when an outsider - Haim Ramon - was elected to run the Histadrut. Ramon served as chairman for only one year. Following the assassination of Prime Minister Yitzhak Rabin in 1995, Shimon Peres (Rabin's successor) nominated Ramon to be minister of health.

As minister of health, Ramon initiated national health insurance which was passed as law on January 1, 1995 (Admati, 2001). The new law separated the Histadrut from the health care services which had been the organization's primary moneymaker, as most of its resources came from membership payments for health services.

\section{Literature Review}

Globalization and capitalism affect trade unions worldwide, as they carry with them distribution of similar patterns in mass production, selling the same products, and a culture of conspicuous consumption (Iranzo and Thanali, 2002; Rainnie, 2006).

Liberal economies go hand in hand with conservative government, and bring about less national and public support (Held \& McGrew, 2002).

Capitalist policies harmed workers' rights by giving a free hand to big corporations. One of the outcomes of a liberalized economy is unemployment, as the unions are powerless and unable to protect the workers (Western, 2002).Trade unions try to fight globalization by become stronger and more competitive, and also by creating international unions (Dabscheck, 2003; Rainnie, 2006).

In the past (Margalit et al., 2000), union representatives signed cooperative agreements with the government and employers. In recent years the employers broke these agreements, with the aim of retiring from cooperative arrangements, and instead benefiting the rich and 
powerful elites. Trade unions today have only small effect of the decision-making process in factories, and on wages and benefits of the working classes. These market conditions demonstrate the vulnerability and uncertainty in workers' lives, as well as an indication of the decline of unions (Kiely, 2003).

The employers are hostile to the unions, and workers who join the union are fired (McCartin et al., 2005). Unions suffer from organizational decline and crisis, they cannot recruit new members and many old members leave the unions (Western \& Craver, 1997; Forrant, 2002; Weil, 2005; Banciu, 2009).

\section{Trade Unions and Privatization}

The privatization process can be defined as "a transaction or transactions utilizing one or more of the methods resulting in either the sale to private parties of a controlling interest in the share capital of a public enterprise or of a substantial part of its assets" (Pamacheche \& Koma, 2007: 4).

The policy of privatization is intended to diminish the activity of the public sector

(Barak- Erez, 2008). During the 70s, privatization accelerated all over the world, as in the England of Thatcher and Major (Katz, 1997). In United States, during Reagan's administration, privatization continued, especially in the field of security. In England and the USA, privatization typically involved the selling of independent businesses as well as goods and services that were under governmental control, such as water, electricity, mail, transportation and fuel (Eckstein and others, 1997).

Most trade unions are hostile to privatization and have played a significant role in the struggle to protect against erosion of salaries by attempting to block privatization (Latham and Ditzler, 2010; Riddell, 2000; Melling, 2004; Kimerling, 1995; Fishman, at el, 2006). In recent years, Australian trade unions have fought against privatization and anti-union and anti-working class laws (Rainnie, 2006). In the case of railway priva- tization at the beginning of the $21^{\text {st }}$ century in Latin America and Africa, the trade unions prevailed, succeeding in protecting and improving the employment conditions of railway workers (Brendan, 2007). But in the case of water privatization in Latin America during the $90 \mathrm{~s}$, the trade unions were divided. Some unions participated in political alliances and supported privatization, while others resisted the process by promoting the interests of workers (Spronk, 2009).

Trade unions are usually dominated by left-wing activists (Simms, 2007; Fishman, at el, 2006), as in Britain's National Union of Rail, Maritime, and Transport Workers. This orientation causes the leaders to militantly oppose privatization in general, and to express grievances over pay and conditions in particular (Darlington, 2009). The effect is to transform political agenda into collective action in the form of strike activity, or even to use the threat of strike action as a bargaining strategy (Kimmerling, 1995; Miller, 2005; Shostak, 2006).

On the other hand, there have been unions which have been more right-wing in their orientation. In the United States, between 1880-1895, John McBride was president of the United Mine Workers of America (UMWA) and was guided by Republican ideology. His approach was rooted in the American Republican tradition that supported capitalism: he saw labor as a means of economic independence for the workers, while embracing right wing government policy that supported privatization (Pierce, 2000). Hayter (2005) describes the British labor movement in the 1960s-1980s which was dominated by right-wing trade union bureaucracy. It supported capitalism and privatization, but began to fracture after Labour's defeat in 1979 and the election of Margaret Thatcher.

\section{Objective Statement}

This article was based on union members that were very subjective and against privatization process. To deal with this bias the researcher based Technique of triangulation (on various sources): leaders that were involved directly in the process, she analyzed also 
organizational documents and daily newspaper. The researcher collected information slowly and carefully, checking to validate the information from each interviewee against other sources.

\section{Research Method}

This research employed qualitative methods, comparing data from two periods. The first period was during the chairmanship of Haim Haberfeld (1992-1994), the second period was that of organizational change under the leadership of Haim Ramon (1994-1995).

Two methods of data collection were used: analyzing documents and interviews.

\subsection{Documents}

Most documents were collected from the Lavon Institute - the Histadrut archive. They included the union's rules and regulations and minutes of the Central Committee and the Secretariat, as well as minutes of conventions. Reports of the Histadrut Inspector were analyzed, and supplemented the information with newspaper articles describing events at the various conventions.

\subsection{Interviews}

Some interviews were open. In these, the interviewees were asked general questions, and a friendly conversation ensued. In most cases, however, the interview was planned, focused, and followed a structured questionnaire adapted to each interviewee.

The interviews were conducted in 2005-2007, and were interviewed a total of 30 people, representing a wide range of Histadrut activists - union leaders, leaders of local branches, Knesset members, and Histadrut administrators. Among those the researcher interviewed were Haim Ramon, the chairman who had initiated the organizational change; MK (member of Knesset) Haim Oron, Histadrut treasurer under Ramon during 1995-1996; former MK Yossi Beilin, one of "Ramon's Eight;" and attorney Gideon BenIsrael, who represented the retirees and had held many administrative positions in the old organization.
All those whose names are listed above gave permission to be quoted. Others asked to remain anonymous. All interviewees had participated directly in the organizational events which they reported to me. The interviewees were found by the "snowball method," where each Histadrut member that was interviewed recommended on other informants. In addition to the interviews, another important source was a book, that was written by union member and the Labor party: Monia Admati's From the Old Histadrut to the New One proved a valuable source of information. Admati was personally acquainted with many union leaders, and they agreed to be quoted in his book based on these relationships. Gideon Ben-Israel's autobiography, The Fighter and the Dreamer, relates to union events and problems. Although I was aware of the subjectivity of these sources, they helped me understand organizational processes. Yitzhak Greenberg's book about the collapse of the Histadrut economic arm Hevrat Haovdim (Society of Workers) supplied me with important background material on the organization. The basis for analyzing the findings was an examination of internal organizational processes and external effects. The analysis is chronological, and is subjective in that it is based on interviewees' opinions. The chronological analysis enabled me to follow the leadership policy in the new Israeli Labor union by connecting internal and external factors.

\section{Findings}

It was Haim Ramon who created massive privatization that transformed the old Histadrut into the new organization. His policy changed the goal system. Firstly, the old goal system will be presented, followed by the new policy, and a comparison of the two.

\subsection{The Goals of the Old Histadrut}

Up until 1994, the goals of the old Histadrut (Hevrat Haovdim, 1990) were achieved by its Hevrat Haovdim, the economic arm through which it supplemented means of livelihood and working, improved workers' living conditions, advanced peripheral areas, solved housing problems, and created economic activity. The 
Histadrut operated in many fields: manufacturing, construction, settlements and agriculture, cooperatives, transportation, finance and development, culture, and activity in Arab and Druze villages. The Histadrut achieved its goals by several means:

\subsubsection{Manufacturing}

Histadrut factories were handled by Hevrat Haovdim. The manufacturing segment of the Histadrut included Koor Industries, a conglomerate operating in cooperation with kibbutz factories. Koor's 280 plants were diversified - electronics, electricity, plastics, metals, chemicals and food. The waves of immigration during the 1950s influenced the Histadrut to establish a new organization - Ti'us (Industry), with the intention of providing employment in peripheral parts of Israel.

\subsubsection{Agriculture}

Tnuva (Produce) was the marketing organization for agricultural produce; it bought products from the farmers and distributed them for sale to the public.

\subsubsection{Building and Constructing}

Solel Boneh (Paver-Builder) was the Histadrut's construction arm. It was founded in 1924, and constructed roads, ports, and power plants, both for the military and civilian purposes.

\subsubsection{Cooperatives}

The Histadrut set up public transportation cooperatives (Egged and Dan), as well as a cooperative of bakeries, and another for building materials.

\subsubsection{Marketing}

Food marketing was conducted through chains of supermarkets and hypermarkets. Hamashbir was the Histadrut owned and run of department store chain for consumer goods (later renamed Hamashbir Lazarchan).

\subsubsection{Finance and Insurance}

Bank Hapoalim (Laborers' Bank) was the financial body of Hevrat Haovdim. The bank was established in 1921 and has supplied bank services from pre-state days until the present day. Hasneh, an insurance company, was established in 1931.

\subsubsection{Culture and Education}

The 1924 Hevrat Haovdim constitution called for "establishing a book publishing house, newspapers, and building schools, libraries, theaters, and institutions for education and culture" (Histadrut, 1990). Berl Katznelson, a prominent Histadrut leader, founded the daily newspaper Davar and Am Oved publishing house. The Histadrut established several other publishing companies with the participation of Tenuat Hakibbutzim (the overall body of kibbutzim affiliated with MAPAI).

\subsubsection{Education}

The Histadrut provided technological education for workers, administrative staff, and youngsters. It had schools nationwide, and these provided vocational training for industry, mechanics, and office work. It also promoted sports activities through Hapoel (The Worker) sports clubs.

\subsubsection{Unionizing}

The Histadrut, being a union, fought for workers' benefits. It sought to improve working conditions, and help and support poor workers. The labor unions negotiated collective arrangements with the government and initiated welfare and social legislation, and the Histadrut itself provided welfare and retirement services (Histadrut, 1994).

\subsubsection{Health Care}

When the Histadrut was founded in 1920, it was with the vision of being not only a union, but a provider of services for workers, including medical services. Kupat Holim (the Histadrut HMO) provided a large variety of medical services (Shvarch, 2002, 2008).

\subsubsection{Pension Services}

The first such fund, Mivtahim, was established in 1954. 


\subsubsection{Culture, Sports, and Leisure for Workers}

The Center for Culture and Sports began its activities in 1975. The center operates six sports and recreation facilities in various parts of the country.

\subsubsection{Women's Advancement and Care}

Na'amat was established in 1921 to promote women's rights, provide legal aid for problems in the family and workplace, and care for abused women and victims of sexual harassment. Na'amat encourages women to acquire education, supports single mothers, and assists them with day care facilities and legal advice (Histadrut, 2002).

\subsection{Privatization under Ramon's leadership in the new Histadrut}

When Haim Ramon was elected chairman, he created changes in the union organization. Ramon wrote (Ramon, 1994-1995):When I was elected in July 1994, the Histadrut was in worse shape than I imagined. Its stagnation had severed it from society. I initiated reforms to rebuild and change the Histadrut, to offer a genuine answer to its members. The Histadrut had been managed politically, and nominations were political. This inefficiency brought about many debts, and the debts were the reason for selling off Histadrut assets.

Selling Histadrut assets - a privatization process. Ramon accelerated the process of privatization policy, and in 1995 it was decided that Hevrat Haovdim would sell $22.5 \%$ of its assets in Koor to the American company Shamrock for $\$ 252$ million. Following this transaction two other companies were sold - Hasneh Insurance and Ti'us ceased to exist, having been sold to business men Yuli Ofer and David Amar. Hasneh properties were sold to two other insurance companies - Migdal and Clal Insurance - for \$185 million. In 1996, one of the Histadrut construction companies (Shikun \& Binui) was sold to Harrison Investment (Greenberg, 2004).
Other businesses were also sold out,in selling medical facilities (clinics and hospitals), the settlement between the Histadrut and Kupat Holim helped cover the Histadrut's NIS 8 million (about $\$ 2$ million) debt ${ }^{\text {ii }}$. By 1994, the Histadrut had debts totaling $\$ 600$ million. Ramon wrote that the Histadrut's Kupat Holim was in total crisis, and that many of those insured had left to other HMOs such as Maccabi. The Histadrut sold all of Kupat Holim property to the state, and, as a headline in the financial newspaper Globes stated on 2 July 2001: "The State's Gift to the Histadrut: A NIS 200 Million Tax Exemption for the Sale of Kupat Holim."

MK Haim Oron, who served as Histadrut treasurer in 1994-1996, said:

The Histadrut had a huge administration without a source of funding. The organization had used the money that was delivered to Kupat Holim, which was in debt for $\$ 1.5$ million, because the organization had used its money for Histadrut political aims. Kupat Holim needed an immediate \$210 million. It had run out of medication and the government decided to close it down. As Haim Haberfeld (the former chairman) said: "We stole money from Kupat Holim and the money was delivered to other Histadrut institutions, when we tried to correct it, it was too late." (Adamati, 2001: 67-68).

Ramon, the new chairman said: "The role of the Histadrut in the past was to rob Kupat Holim of its money. Some $30-40 \%$ of Kupat Holim funds financed Histadrut needs. Members of the Histadrut wanted health care services, not Histadrut services."

Ramon said: "Kupat Holim did not incur losses. The losses were caused by political nominations in the Histadrut, whose 4,000 employees were engaged directly or indirectly - in political activity." Ramon referred to the Histadrut as "the sinking Titanic" (Ramon, 1994-5).

\footnotetext{
ii www.ramon.co.il
} 
According to Meir Gat, Haberfeld's assistant:

Kupat Holim became corrupt, employing large numbers of unnecessary people for political reasons. There was a lot of talk about instituting reforms in Kupat Holim but nothing was done. The taxes did not cover expenses.

Similar ideas were expressed by Efraim Zilony, chairman of the professional union: "Ramon's actions were based on political views rather than economic ones. He said that the new body will be devoid of political identity. But he actually wanted to replace the old workers with his supporters." Zilony thought that the new leaders had not bargained with the state after delivering most of its assets, and the Histadrut still remained in debt. Eli Nachmias, treasurer of the Haifa branch, criticized Ramon's privatization process:

In the past the Histadrut had 4,000 employees. He [Ramon] laid off almost $75 \%$ of the administration, a move unprecedented anywhere. Ramon gave very generous retirement settlements to the workers, and by doing so, created heavy debts for the organization. Ramon gave the state a present of 100 clinics and 15 hospitals, and created a debt of 400 million dollars. The Histadrut relinquished 12 expensive buildings in Haifa and Tel Aviv and even with that, its debts were not covered.

Like Zilony, Nachmias also accused Ramon of making political moves. Most of the interviewees claimed that in every union the management wants to empower the organization, not weaken and destroy it. Ramon viewed labor unions as archaic and redundant, and his political position was close to right-wing Labor party circles including those of Prime Minister Rabin. Ramon and Rabin acted together out of mutual interest.

Professor Danny Gutwein, who was consultant to Amir Peretz, former chairman of the Histadrut, explained that Ramon's moves toward privatization expressed his identification with the interest of the capitalists in Israel:
Ramon saw the Histadrut as a problem. He came with views of middle-class morality and participated in the policy of privatization in Israel. The policy of the labor unions was to serve the poor and establish a welfare state. He [Ramon] and Prime Minister Rabin acted out of the same interests; they saw the Histadrut as interference, and wanted to weaken the labor unions.

Haim Oron justified privatization:

All Histadrut institutions were bankrupt. The construction firm Shikun \& Binui had to sell Histadrut property. Buildings were mortgaged to banks. The Histadrut newspaper Davar had large debts after the Histadrut invested a lot of money in it; the management put 5 million dollars in the newspaper, but eventually it collapsed and was closed.

Other Histadrut institutions were bankrupt as well. In my interview with him, Eli Nachmias, treasurer of the Haifa branch, told me that the 15 lending libraries were all closed down. The collapse of the libraries symbolized the general condition of the Histadrut.

Histadrut sports services were also privatized. In 1994, the 17th Histadrut Convention decided to reform the sports system. According to this decision, leisure sports activities for the public would continue operating (but professional sports teams were to be sold to public or private enterprises). Payments for any sports clubs or facilities were to be made directly to the sports team and not through Hapoel, the sports department of the Histadrut. Hapoel was now in charge of establishing policies, consulting, and organizing sports events for the public, but was stripped of all managerial responsibilities.

As Eli Nachmias told me (the treasurer of Haifa branch), that the new Histadrut stopped financing professional sports, and a new Common Council for Sports (Ramon, 1994-1995) was established. The professional Hapoel sports teams were sold to pay off a $\$ 2$ million debt. In addition, many local branches of the Histadrut were closed. Of the 937 branches that had 
existed before 1994, only $20 \%$ remained. Here, again, most of the employees were laid off.

\subsection{Goal transformation in the new Histadrut: Comparing the old goal systems and the new one}

The crisis in the old Histadrut caused a radical change in the goal system. Meir Gat said that the new Histadrut lost its special nature, as in the past the organization had given general services to the entire Israeli population. The Histadrut had been deeply involved national social and financial affairs, and instrumental in determining government policy regarding income, wages, and the standard of living.

Histadrut activity in the past was based on big budgets which gave it a free hand. In Munia Adamty's words:

In the past the Histadrut taught its union representatives, they had legal knowledge. They knew how to appear in labor courts. The Histadrut had a school for activists, and it was financed by its former chairman Kaisar. When I left the organization, there were no budgets and no activities.

One of the chairmen of the professional unions in northern Israel recounted how goal displacement takes place in Histadrut activity:

The change is in the activity of the professional union. In the past membership in the Histadrut was taken for granted, but this is no longer the case. Today I have to pursue each member to please him. In my duty I take care of members, problems, and when they address me when they have professional problem is the time to recruit them to the union. I have to go from one factory to another to convince them that the union is supplying various services: legal aid, professional aid, and improvement in work's conditions. Mostly, the workers are afraid to address the Histadrut, because their employers are against it. This information was common to other interviewees, all of whom emphasized the special role of the professional union.

\section{Discussion}

Ramon, the new Histadrut leader, initiated privatization and downsizing that affected goal transformation in the organization, but there were external factors that also contributed to this process. Israeli society had become more ideologically right-wing, and this political orientation made the organizational environment hostile to the Histadrut. The new atmosphere meant that fewer funds were channeled from the government to the Histadrut, and lack of resources forced the organization to implement changes that transformed the goal system. The old Histadrut leadership before Ramon ignored organizational problems. They managed, until 1994 , on a socialistic agenda without consideration of the economic cost.

The old Histadrut spent large amounts of money, and its former leader Haberfeld was reluctant to cut expenses. He did not want to fire members of the Histadrut, because they and their families would not support them in future internal elections. The Israeli Labor party controlled the Histadrut and was interested in the continued existence of Histadrut-controlled factories. By providing employment, the Histadrut and its patron the Labor party earned public support. Labor leaders were concerned with being reelected in the general election, even at the price of maintaining inefficient organizations and factories (Greenberg, 2004).

Managerial failure and the resultant bad publicity undermined Histadrut legitimacy. Ramon's policies affected the process of privatization and downsizing. When he left the union he initiated the 1995 national health care legislation which cut the Histadrut off from its main source of financing, and the problem of lack of resources became a major threat to its existence.

The economic, political, ideological, and sociological environment was changing (Bozman, 2002); as Israeli society became more capitalistic and right-wing, governments were no longer interested in protecting 
Histadrut assets (Held \& McGrew, 2002). In pre-state days and up to 1977, MAPAI and other labor parties in government had taken care of Histadrut interests. The Likud government of 1977 acted with hostility toward the Histadrut (Greenberg, 2004), and as a result, the Histadrut became debilitated and struggled for its survival, as did other unions world-wide (Western, 1995; Craver, 1997; Forrant, 2002).

Ramon deliberately directed the goal system towards his own ideological and political ends and needs. Out of conviction for his right-wing views, he decided to sell most of its assets in order to cover its debts. He did not try to save the Histadrut from privatization; although he was Histadrut chairman for only one year, during this short period he managed to dismantle most of the Histadrut assets. As a young leader, Ramon worked alongside Yitzhak Rabin's coalition in the Labor party. $\mathrm{He}$ and Rabin were aware of the negative image of the Histadrut, and they thought that the association between their party and the Histadrut would harm them in their election campaign. The Israeli public despised the Histadrut for its corruption and inefficient management, and Ramon had the public's mandate to destroy the organization.

The Israeli public was deeply hostile towards the Histadrut, Ramon thought that the destruction of the Histadrut would serve his political aspirations.

Ramon's ideas were right-wing (Pierce, 2000). His policy of promoting privatization led to the loss of the majority of Israeli Labor union assets. His leadership was unusual: most union leaders protect and fight for union members' rights (Riddell, 2000), strive to empower their organization (Melling, 2004; Willis, 1988; Pierce, 2000; Weil, 2005; Banciu, 2009) or to prevent union downsizing (Rainnie, 2006). Ramon wanted to destroy the unions and he acted against the members and leaders in the Israeli Labor Federation. Ramon saw the unions as a means to his end: becoming leader of the Israeli Labor party. But his policy backfired; his actions caused many union members to lose their jobs, and to hate Ramon, and he finally left the Labor party.

Ramon did not defend union members as most union leaders would do. He dismissed many union members and encouraged privatization, and this harmed cohesiveness and solidarity among the union's workers (Darlington, 2009). Ramon actions were motivated by capitalistic ideology (Pierce, 2006; Hayter, 2005); his orientation had considerable effect on the Histadrut goal system: Ramon worked hard to diminish and minimize its activities.

The present case study reveals processes similar to those in other trade unions worldwide, as a result of downsizing (Dolvik and Waddington, 2004; Humphrey, 2000; Voss and Sherman, 2000; Rainnie, 2006) and decline, but this case study is unique and different from those of other unions because of the leader's attitude: Ramon acted against the interests of his own union members and identified with privatization. The old organization and its leaders ignored the changes and did not implement the necessary steps, causing the organization to eventually collapse (Greenberg, 2004). Ramon's privatization policy forced the Histadrut to focus on its trade-union trade goals.

We can understand the hostility of union members and employees toward privatization, as Ramon's reforms minimized their organization's importance and caused massive downsizing of Histadrut jobs. They saw their organization being destroyed, and although Ramon's measures were necessary, they could not accept them.

Although the old Histadrut ran according to political interests, it also wanted to defend the workers and to help them to survive in the early years of the new state of Israel, and played a significant part in building the new state. If the Histadrut's leaders had been concerned only with economic principles, the new immigrants would not have had any means of livelihood. By its socialistic values, the Israeli labor unions took care of the poor and needy and helped the Israeli labor party to 
establish and maintain the new society. Their socialistic orientation suited the needs of the new-born country, and the Israeli labor unions were the primary channels for achieving the goals of the nascent society.

Whereas most labor unions resisted the process of privatization in other organizations, this case study describes privatization in the labor union itself. This can be explained by the fact that until 1994 the Histadrut was a unique phenomenon; it combined the interests of working, middle and upper classes, and fulfilled widespread social goals. A conflict of interest existed in that on one hand it represented blue collar workers, while on the other, the Histadrut was itself a substantial employer, taking care of managerial well-being as well. The privatization process in the Israeli labor unions caused the organization to focus on its traditional goals, thereby losing its uniqueness and coming to resemble other trade unions in the world.

\section{Conclusion}

The privatization process was an outcome of organizational decline and poor management that created heavy debts for the old Israeli unions. The Israeli labor unions lost their legitimacy in society, and an outsider was elected to run the organization. The new leader was capitalistically oriented, and pursued a privatization policy to cover the union's losses. The privatization process in the Israeli labor unions created a new organization focusing on its trade union's goals, loosing its uniqueness as a society-wide entity.

\section{References}

Admati, M. (2001). From the Old Histadrut to the New One. Tel Aviv: Histadrut Publications. (in Hebrew).

Akershtain, S., Zilberperb, B. Z., \& Rozebitz, S. (1997). Privatization of firms in Israel and the world. Bar Ilan University: Ramat Gan. (in Hebrew).

Banciu, A. (2009). Institutional Reform in the European Union. Geopolitics, History and International Relations, 1(2), 139-143.

Barak, Erez, D. (2008). The public trail of privatization: models, norms and challenges. Law review, (30)3, 461515.

Bartal, G. (1989). The Histadrut: Structure and Activities. Tel Aviv: Histadrut Publications. (in Hebrew).
Behrens, M., Hamann, K., \& Hurd. R. (2004). Conceptualizing Labour Union Revitalization. In C. M. Frege \& J. E. Kelly (Eds.), Varieties of Unionism: Strategies for Union Revitalization in a Globalizing Economy (pp. 11-19). New York: Oxford University Press.

Bozeman, B. (2002). Public Value Failure: When Efficient Markets May Not Do. Public Administration Review, 62(2), 145-161.

Brendan, M. (2007). The world bank, railways privatization and trade unions. International Trade Union Cooperation, 4, 3-10.

Cornfield, D. B., \& Mccammon, H. J. (2003). Revitalizing Labor: Global Perspectives and a Research Agenda. Research in the Sociology of Work, 11, 1-20.

Dabscheck, B. (2003). International Unionism's Competitive Edge: FIFPro and the European Treaty. Industrial Relations, 58(1), 85-108.

Darlington, R. (2009). Leadership and Union Militancy: The Case of the RMT. Capital \& Class, 99, 3-32.

Dolvik, J. E., \& Waddington, J. (2004). Organizing Marketized Services: Are Trade Unions Up to the Job? Economic and Industrial Democracy, 25(1), 9-40.

Fishman, N., Prazmowska, A. J., \& Heith, H. (2006). Communist Coalmining Union Activists and Postwar Reconstruction, 1945-52: Germany, Poland and Britain. Science \& Society, 70(1), 74-97.

Forrant, R. (2002). The International Association of Machinists, Pratt \& Whitney, and the Struggle for a BlueCollar Future in Connecticut. International Review of Social History, 47(S10), 113-136.

Greenberg, L. L. (1993). The Histadrut Above All. Jerusalem: Nevo Publishing. (in Hebrew).

Greenberg, Y. (2004). Anatomy of Crisis Foretold: The Collapse of Labor Owned Enterprises in the 80s. Tel Aviv: Am Oved. (in Hebrew).

Hayter, D. (2005). How the Right Made Labour Safe for Business. Manchester: Manchester university press.

Held, D., \& McGrew, A. G. (2002). The Global Transformations Reader. Great Britain: Library of Congress.

Hevrat, Haovdim. (1990). The aim is participation and involvement in Hevrat Haovdim. Tel Aviv: Lavon Institution. (in Hebrew).

Histadrut. 1990. The Aim is Participation and Involvement in Hevrat Haovdim. Tel Aviv. (in Hebrew).

Histadrut. (1994). Minutes of the Histadrut $17^{\text {th }}$ Convention. Tel Aviv: The New Histadrut. (in Hebrew).

Histadrut. (1995). Minutes of the Report of the Histadrut controller. Tel Aviv: Histadrut. 
Histadrut. (2002). Minutes of Histadrut $19^{\text {th }}$ Convention. Tel Aviv: The New Histadrut. (in Hebrew).

Horowitz, D., \& Lisak, M. (1977). From pre-state to the State. Tel Aviv: Am Oved. (in Hebrew).

Humphrey, J. C. (2000). Self-organization and Trade Union Democracy. The Sociological Review, 48(2), 262-282.

Iranzo, C., \& Patruyo, T. (2002). Trade Unionism and Globalization: Thoughts from Latin America. Current Sociology, 50(1), 57-74.

Kelly, J. (2005).Social Movement Theory and Union Revitalization in Britain. In S. Fernie and D. Metcalf (Eds.), Trade Unions: Resurgence or Demise? (pp. 62-82). London: Routledge.

Kiely, R. (2003). The Race to the Bottom and International Labor Solidarity. Review: A Journal of the Fernand Braudel Center, 26(1), 67-88.

Kimmerling, B. (1995). Between State and Society: The Sociology of Politics. Tel Aviv: The Open University. (in Hebrew).

Latham, J. M. and Dizler, W. E. (2010). Collective Effort: The American Union and the American Public Library. Library Trends, 59(1-2), 237-255, 374-375.

Mangum, G. L., \& Mangum, S. L. (1993). Assessing Alternative Employment - Relations Systems Mangum. Challenge, 36(4), 29-38.

McCartin, A. J., Compa, L., \& Friedman, S. (2005). Democratizing the Demand for Workers' Rights/ A Response. Dissent, 52, 61-72.

Melling, J. (2004). Leading the White-Collar Union: Clive Jenkins, the Management of Trade-Union Officers, and the Politics of the British Labour Movement, c.19681979. International Review of Social History, 49, 71-102.

Miller, D. (2005). Regional Solidarity and a New Regional Movement in Post-apartheid Southern Africa: Retail Workers in Mozambique and Zambia: Labour, Capital, and Society. Labour, Capital and Society, 38(1/2), 94-125.

Pamacheche, F., \& Koma, B. (2007). Privatization in SubSaharan Africa - an essential route to poverty alleviation. African Integration Review volume, 1, 1-22.

Pierce, M. (2000). The Populist President of the American Federation of Labor: The Career of John McBride, 18801895. Labor History, 41, 5-24.

Rainnie, A. (2006). The Future of Worker Representation. Capital \& Class, 30(2), 169-174.

Ramon, H. (1994-5). Minutes of Histadrut chairman's report, The Elected Representatives of the Histadrut, July 1994-November 1995, p. 3. (in Hebrew).
Ramon, H. (1995). The Histadrut - The Sinking Titanic. Histadrut, Unpublished internal document. (in Hebrew).

Rao, B. S. (2004). New Social Forces in India. Foreign Affairs, 23(4), 635-643.

Reinhart, T. (1999). How the Histadrut was destroyed. Mit'an, 10, 1-3. (in Hebrew).

Shapiro, Y. (1977). Israeli Democracy. Ramat-Gan, Israel: Massada. (in Hebrew).

Shostak, B. A. (2006). Finding Meaning in Labor's Perfect Storm: Lesson from the 1981 PATCO Strike. Employee Responsibilities and Rights Journal, 18(3), 223-229.

Shvarts, S. (2002). The Workers' Health Fund in Eretz Israel: Kupat Holim, 1911-1937. New York: The University of Rochester.

Shvarts, S. (2008). Health and Zionism. New York: The University of Rochester.

Simms, M. (2007). Interest Formation in Greenfield Union Organizing Campaigns. Industrial Relations Journal, 38(5), 439-454.

Spronk, S. (2009). Water privatization and the prospects for trade union revitalization in the public sector: case studies from Bolivia and Peru. Just Labour: A Canadian Journal of Work and Society, 14, 164-176.

Stirling, J. (2005). There's a New World Somewhere: The Rediscovery of Trade Unionism. Capital \& Class, 29(3), 43-63.

Weil, D. (2005). A Strategic Choice Framework for Union Decision Making. Working USA, 8(3), 327-347.

Western, B. (1995). A Comparative Study of Working-Class Disorganization: Union Decline in Eighteen Advanced Capitalist Countries. American Sociological Review, 60(2), 179-201.

\section{About the Author}

Yaffa Moskovich, Ph.D., is a senior lecturer and head of Behavioral Sciences department at Zefat academic College in Israel. whose expertise is in the field of political and organizational sociology. She is the author of articles and a book about the Israeli Likud Party, Disunity in Unity: Power Struggles inside the Likud Party from 1972-2002. Her work also involves organizational change, leadership in political parties, unions, civil society organization and multi cultural group relationship. Her recent research is about civil society organizations in immigration field. She received her Ph.D. from Bar Ilan University. She can be reached at mosko777@gmail.com 